\title{
Literatura w sytuacji zagrożenia języka: wokól krytyki górnołużyckiego przekładu książki dla dzieci
}

DOI: http://dx.doi.org/1 0.12775/LC.2019.022

Streszczenie: Literatura wydawana w języku mniejszościowym, zwłaszcza przeznaczona dla dzieci, jest inaczej oceniana przez przedstawicieli mniejszości niż literatura pisana w języku dominującym. Wiąże się to z wyznaczonymi dla niej rolami: ma ona nie tylko odpowiadać na potrzeby artystyczne grupy, ale także nauczać młode pokolenie używania języka mniejszościowego w wersji literackiej. Oznacza to, że autorzy i wydawcy tej literatury są w pewnej mierze ograniczeni przez stawiane im wymogi. Artykuł przedstawia dyskusję toczącą się na Górnych Łużycach w Niemczech w związku z publikacją łużyckojęzycznego przekładu czeskiej książki dla dzieci Puntíkárí (łuż. Šwintuchaj) napisanej przez Miloša Kratochvíla. Tłumaczom zarzucano używanie licznych germanizmów, języka potocznego oraz niepoprawnych form językowych. Twierdzono, że literatura napisana w języku mniejszościowym musi spełniać przede wszystkim misję edukacyjną i promować język literacki. W oparciu o tezy stawiane przez recenzentów i krytyków książki analizuję panujące na Łużycach ideologie językowe (takie jak ideologia autentyczności języka, jego czystości, własności), rolę mikroliteratur (zwłaszcza ich rolę edukacyjną i rozrywkową), a także ograniczenia dla twórców i wydawców literatury w językach mniejszościowych. Przyglądając się dyskusji toczącej się wokół książki zastanawiam się, czy tego rodzaju dyskusja świadczy o żywotności grupy, czy o jej złej kondycji.

Słowa kluczowe: literatura w języku mniejszościowym, górnołużycki, przekład, ideologie językowe, język literacki

\footnotetext{
* Prof. w Instytucie Slawistyki Polskiej Akademii Nauk, kulturoznawczyni i socjolingwistka. Do jej zainteresowań badawczych należą: problematyka tożsamości europejskich mniejszości językowych, metody ochrony i rewitalizacji języków i kultur mniejszościowych, wielojęzyczność oraz wielokulturowość.

E-mail: nicoledolowy@gmail.com | ORCID:0000-0001-7256-8226.
} 


\title{
Literature in the Context of Language Endangerment: Concerning Criticism of the Upper Sorbian Translation of One Book for Children
}

\begin{abstract}
Literature published in a minority language - especially children's literature - is evaluated by representatives of minorities differently from literature written in the dominant language. This situation is related to the roles assigned to literature in the minority language: not only is it supposed to answer to the artistic needs of the group, but also it is expected to teach the young generation how to use a minority language in its literary version. This means that the requirements imposed on the authors and publishers to some extent limit their creative freedom. The article presents the currently ongoing debate in Upper Lusatia, Germany with regard to the publication of an Upper Sorbian translation of the Czech book for children Puntikáríi (Upper Sorbian: Šwintuchaj) written by Miloš Kratochvíl. The translators are alleged to have used numerous lexical borrowings from the German language, colloquial language and incorrect language forms. Other objections concerned the translation's lack of educational objectives, which are assumed to be a mission of the minority language literature, and its rejection of the role of promoting the literary language. Based on the book reviewers' and critics' theses I analyse the language ideologies existing in Lusatia (such as the ideology of language authenticity and pureness or the ideology of language ownership), the role of micro-literatures (particularly their educational and entertainment functions), and limitations encountered by the writers and publishers of literature in minority languages. Looking at the community debate surrounding the book, I discuss whether it testifies to the community's vitality or conversely to its weak condition.
\end{abstract}

Keywords: minority language literature, Upper Sorbian, translation, language ideologies, literary language

dyby znaczenie książki mierzyć miarą dyskusji wywołanej jej publikacją, górnołużycki przekład czeskiej książki Puntíkáři napisanej przez Miloša Kratochvíla (2009) byłby najważniejszą chyba pozycją górnołużyckiej literatury XXI wieku. Oczywiście takie stwierdzenie jest kontrowersyjne, mamy tu bowiem do czynienia z przekładem - więc dziełem w pewnym sensie wtórnym, a w każdym razie takim, którego nie można zaliczyć do kanonu literatury łużyckiej. Co więcej, to literatura dziecięca, niewielkich rozmiarów książeczka, opatrzona ilustracjami, taka, której treść ma nawiązywać do codziennych przeżyć odbiorców, którzy przynajmniej do pewnego stopnia mogą się utożsamić z językiem postaci. Nie jest to jednak powieść poważna ani ważna z punktu widzenia łużyckiej społeczności czy jej kultury. 


\section{Górnołużycki kontekst i książka}

Żeby zrozumieć znaczenie dyskusji, która wokół górnołużyckiego tłumaczenia książeczki dla dzieci się zrodziła, musimy zdawać sobie sprawę zarówno z sytuacji samego języka, jak i innych dylematów mniejszości łużyckiej związanych z ochroną i strategiami zachowania jej języków. Otóż Łużyczanie są jedną z najmniejszych rozpoznanych europejskich mniejszości autochtonicznych. Zamieszkują niewielki obszar Łużyc, leżących w niemieckich landach Saksonii w okolicach Budziszyna (Bautzen/Budyšin, Górne Łużyce) i Brandenburgii wokół Chociebuża (Cottbus/Chóśebuz, Dolne Łużyce), niedaleko granicy z Czechami i Polską. Łużyczanie posługują się dwoma językami należącymi do rodziny języków zachodniosłowiańskich - górnołużyckim i dolnołużyckim. Ze względu na różnice w historii tych grup, wynikające z polityki, też historycznej, landów, nierównej dyskryminacji i prześladowań użytkowników tych języków, tożsamości religijnej Łużyczan, a także przemian ekonomicznych w regionach (Dołowy-Rybińska 2012) - języki łużyckie znajdują się obecnie w różnej sytuacji socjolingwistycznej. Podczas gdy na Dolnych Łużycach przekaz międzypokoleniowy języka został przerwany już w latach trzydziestych XX wieku i pozostała jedynie garstka natywnych użytkowników tego języka (liczonych na od kilkuset do maksymalnie 2000 osób; Norberg 1996; Jodlbauer, Spiess, Steenwijk 2001), język górnołużycki jest wciąż używany przez około 10-12-tysięczną wspólnotę górnołużyckich katolików zamieszkujących niewielki, lecz zwarty językowo obszar koło Budziszyna, na którym osoby należące do wszystkich pokoleń posługują się językiem górnołużyckim (Walde 2004; Elle 2010). To właśnie górnołużycki jest językiem przekładu omawianej książki.

Niemniej sytuacja języka górnołużyckiego również zmienia się w ostatnich latach: wraz z przemianami politycznymi, które dały mieszkańcom NRD swobodę zmieniania miejsca zamieszkania, z pogarszającą się sytuacją ekonomiczną regionu, nasilającą się migracją oraz wzrastającą liczbą mieszanych małżeństw, liczba dzieci znających język łużycki zaczęła maleć. Jednocześnie, w związku z koniecznością podjęcia działań rewitalizacyjnych, stopniowo coraz więcej dzieci z domów niemieckojęzycznych (potomków zasymilowanych Łużyczan oraz Niemców, którzy nie mają łużyckich korzeni, ale zamieszkują w regionie) ma możliwość uczenia się języka łużyckiego, np. w immersyjnych przedszkolach „Witaj” czy poprzez dwujęzyczny system nauczania 2plus (Budarjowa 2009; Gantefort, Roth, Migai, Gogolin 2010; Dołowy-Rybińska 2011).

Nie bez znaczenia dla dzisiejszej sytuacji języków łużyckich są działania podjęte po II wojnie światowej przez komunistyczny rząd NRD, nastawione na pomoc temu „najmniejszemu słowiańskiemu narodowi”. Już pod koniec lat czterdziestych XX wieku na Łużycach powstała cała infrastruktura językowa, której pozazdrościłaby im niejedna europejska mniejszość: od szkół (łużyckojęzycznych lub dających możliwość uczenia się łużyckiego), przez instytucje naukowe, badawcze i kulturalne, dwujęzyczne tablice na obszarze Łużyc, aż po założone w 1958 roku wydawnictwo - Ludowe Nakładnistwo Domowina (Domowina-Verlag), wydające nie tylko codzienną prasę w języku górnołużyckim, ale także publikujące książki, zarówno naukowe, jak i popularne, poezję i beletrystykę, pozycje dla dorosłych i dla dzieci - w językach łużyckich. Po zmianie systemu politycznego i zjednoczeniu Niemiec Łużyczanom udało się zachować instytucje funkcjonujące w NRD, jak również ich finansowanie, poprzez stworzoną w 1991 roku Fundację na rzecz Narodu Łużyckiego 
(Dołowy-Rybińska 2011). Tym samym Łużyczanie dysponują dziś środkami, żeby wydawać literaturę w swoich językach. Jednocześnie jednak Ludowe Nakładnistwo Domowina pozostaje jedynym łużyckim wydawnictwem, zaś jego funkcjonowanie silnie związane jest z prowadzoną na Łużycach polityką językową.

Górnołużycki tytuł Šwintuchaj (2014) nie oddaje wieloznaczności czeskiego oryginału. Odnosi się do dwóch głównych bohaterów książki, przyjaciół „na śmierć i życie”, Michała i Filipa. Zachowanie chłopców i przeżywane przez nich przygody często odbiegają od przyjętych powszechnie w szkole norm, w związku z czym mają wstawiane do dzienniczków czarne kropki (stąd tytuł Puntíkáŕi, który po polsku można by oddać jako „Kropkowcy”). Oprócz chłopców w opowiadaniu pojawia się cały wachlarz postaci: rodzina, nauczyciele, znajomi, każdy charakterystyczny, mający swoje wady i zalety, sposób mówienia i przemyślenia. Książka napisana jest dowcipnie. Imitacja myśli i słów dzieci, podkreślanie ich cech, przedstawienie innych postaci sprawiają, że czyta się ją łatwo i przyjemnie. Nie jest to jednak literatura, którą można uznać za oryginalną. Choć opowieści i postaci są wytworem wyobraźni Kratochvíla, pomysł wydaje się powieleniem słynnego francuskiego Mikołajka (Le Petit Nicolas) autorstwa René Goscinnego i Jean-Jacques'a Sempé. Podobnie jak w przypadku Mikotajka książka Puntikáři jest przeznaczona zarówno dla dzieci, które wciągać może opowieść i perypetie bohaterów, jak i dla rodziców, którzy mogą cieszyć się z języka postaci, zwłaszcza dziecięcych, a także z trafnego wypunktowania cech charakterów.

Żeby dopełnić wstępnego obrazu książki, kilka słów należy też napisać o autorach przekładu górnołużyckiego, małżeństwie Jadwidze i Fabianie Kaulfürstach. W środowisku łużyckiej inteligencji obydwoje są świetnie znani, zarówno jako osoby odpowiedzialne za przyszłość języków łużyckich (Jadwiga Kaulfürstowa jako pracownica Językowego Centrum „Witaj”, instytucji odpowiedzialnej za politykę językową, zwłaszcza edukacyjną, na Łużycach; Fabian Kaulfürst jako naukowiec, językoznawca, pracujący w dolnołużyckim oddziale Instytutu Łużyckiego, najważniejszej instytucji zajmującej się badaniami w obrębie kultury łużyckiej), jak i jako animatorzy łużyckiego życia kulturalnego, muzycznego, organizacyjnego. Należący oboje do młodego pokolenia Łużyczan, których działanie rozpoczęło się już po likwidacji NRD i zjednoczeniu Niemiec, Jadwiga i Fabian Kaulfürstowie są symbolami aktywistów językowych działających - co się rzadko zdarza - na rzecz obu języków: górno-i dolnołużyckiego. Choć to nie oni byli pomysłodawcami stworzenia tego przekładu, krytyka, a także dyskusja wokół tej książki odnosi się w dużej mierze do ich wyborów językowych i stylistycznych.

Nie przypominam sobie, żeby w ciągu ostatnich 12 lat, od kiedy badam problematykę związaną z kulturą łużycką, jakakolwiek książka „nierozliczeniowa” ${ }^{1}$ wywołała taki odzew odbiorców i taką krytykę. Od wydania jej wersji drukowanej w 2013, przez pojawienie się jej wersji fonograficznej w 2016 roku, dyskusja o roli, znaczeniu i zagrożeniach związanych z przekładem tej książki nie słabnie. Jest ona prowadzona zarówno publicznie, na łamach łużyckiej prasy codziennej („Serbske Nowiny”), kulturalnej (miesięcznik „Rozhlad”), jak i w kuluarach - w różnych środowiskach łużyckiej inteligencji. Przez długi czas po ukazaniu się książki niemalże cała łużycka elita o niej rozmawiała. Większość dyskusji prowadzonych

1 Książki „rozliczeniowe”, zwłaszcza odnoszące się do działalności Łużyczan w NRD, wywołują szerokie dyskusje, czego najlepszym przykładem mogą być publikacje historyka Timo Meškanka, np. Kultura w słužbje totalitarneho režima. Budyšin: Ludowe Nakładnistwo Domowina (2011). 
zaraz po publikacji w gronie górnołużyckiej inteligencji, choćby dotyczyły kwestii zupełnie z książką niezwiązanych, schodziła w końcu na rozmowę o niej. Jej recenzenci (i piszący, i dyskutujący o niej nieformalnie) podzielili się wyraźnie na dwie grupy, reprezentujące znacznie więcej niż tylko stosunek do książki czy nawet literatury dziecięcej w języku mniejszościowym. To dwie strony sporu, czym dziś jest kultura łużycka i jej języki, jak mają wyglądać w przyszłości i jakie mogą być ich granice.

Artykuł ten nie ma charakteru ani literaturoznawczego, ani językoznawczego. Omawiana tu książka i dyskusja, która się wokół niej wywiązała, są jedynie punktem wyjścia do rozważań o roli literatury we wspólnocie mniejszościowej. Przeanalizuję też sytuację języka mniejszościowego, odwołując się do opinii o jego roli w społeczności. Zastanowię się, jakie oczekiwania wobec literatury pisanej w języku mniejszościowym mają zarówno przedstawiciele tej grupy, jak i instytucje wyznaczające kierunki polityki językowej. Rozważę, czy istnieją i gdzie granice swobody twórczości w tych językach. Tym samym artykuł ten nie stawia sobie za zadanie oceny ani samej książki, ani jej przekładu. Ma natomiast pokazać problemy, z jakimi mierzyć się muszą małe języki, a które mają wpływ na to, co i jak w literaturze w językach mniejszościowych jest wydawane. Kluczowe dla mnie pozostaje więc pytanie: o czym świadczy tak duże poruszenie wydaniem książki. Wiąże się z tym również kwestia, czy literatura mniejszościowa jest literaturą taką samą jak inne, a jeśli nie, to dlaczego i jakie są/mogą być tego konsekwencje.

\section{Język literacki versus język potoczny}

Najpoważniejsze - powtarzające się we wszystkich publikowanych recenzjach (zob. literatura podmiotu) książki Šwintuchaj - zarzuty dotyczą języka przekładu: zarówno jego formy, stylizacji, jak i konkretnych wyborów tłumaczy oraz stosowania przez nich germanizmów. Sama dyskusja sięga jednak znacznie dalej niż tylko w tajniki warsztatu translatorskiego. Dotyczy ona bowiem tego, co dla przyszłości języka górnołużyckiego, a pośrednio wszystkich języków mniejszościowych, jest fundamentalne - w jaki sposób chronić ten język nie tylko przed przerwaniem transmisji międzypokoleniowej, ale także przed jego ubożeniem i „psuciem” rozumianym jako „zanieczyszczanie” coraz liczniejszymi zapożyczeniami z języka dominującego. W tle tej dyskusji pobrzmiewają natomiast echa ideologii językowych dotyczących autentyczności języka i języka standardowego.

Jednym z ważnych elementów krytyki języka przekładu są pojawiające się w książce zapożyczenia z języka niemieckiego (zob. Sankoff 2001). Niektórzy recenzenci uważają je za niepotrzebne (można w to miejsce wstawić słowa o łużyckiej etymologii), inni wręcz za niebezpieczne (zapożyczenia z niemieckiego pojawiające się w łużyckojęzycznej literaturze degradują ten język, sankcjonują też jego niszczenie). Stosowanie zapożyczeń jest jednak tylko jednym z zarzutów krytyków. Weronika Žurowa (2016) w recenzji napisanej w „Serbskich Nowinach” z okazji wydania audiobooka Šwintuchaj przypomina, że zarówno wydawnictwo, jak i tłumacze oskarżani są o to, że propagują niepoprawny, potoczny język i go w ten sposób upowszechniają. Zarzut ten pokazuje, że w przypadku literatury pisanej w języku mniejszościowym już forma potoczna jest uważana za niepoprawną, nie zaś - jak w przypadku literatury w silnych językach - jako jeden z możliwych rejestrów. Do ideolo- 
gicznego wydźwięku tego określenia jeszcze powrócę. Žurowa stawia pytanie, czy można dopuścić do odchyleń od normy językowej w oficjalnych publikacjach jedynego łużyckiego wydawnictwa. Zwłaszcza jeśli misją literatury mniejszościowej ma być zachowanie i ochrona poprawnego języka. Recenzentka na to pytanie nie chce jednoznacznie odpowiedzieć. Jednak inni recenzenci nie mają takich rozterek.

W anonimowej recenzji również zamieszczonej w dziale Dyskusje w „Serbskich Nowinach” (2014) można przeczytać, że książka dla młodych ma być oczywiście napisana językiem dla dzieci zrozumiałym, ale odpowiadającym temu, którego uczą się w szkole. Książka górnołużycka ma bowiem propagować poprawny język i go chronić, a nie upowszechniać niepoprawne formy. Recenzentka uważa, że samo wydanie w formie pisanej treści w języku potocznym, a tym bardziej niepoprawnej (bo imitującej błędy językowe popełniane przez dziecko), może zaszkodzić dzieciom, które nie będą w stanie zrozumieć zabiegów literackich, utrwalą sobie natomiast błędne formy i zaczną ich używać. Recenzja kończy się stwierdzeniem, że dzieci powinny najpierw nauczyć się dobrze i poprawnie mówić po łużycku, zanim zostaną skonfrontowane $\mathrm{z}$ innymi formami. Autorka tekstu uważa wręcz, że książka nie tylko nie straciłaby nic, ale - i to na wielu poziomach - zyskała, gdyby niepoprawne formy używane w oryginale w wersji łużyckojęzycznej zastąpić językiem poprawnym, zaś język potoczny przekształcić w literacki.

Jedynie nieliczne głosy stają w obronie przekładu. Michał Nuk w recenzji wydrukowanej w „Serbskich Nowinach” (2014) podkreśla, że dyskusja, w której bierze udział, nie dotyczy już książki jako takiej, ale stała się debatą wokół języka łużyckiego i jego misji. Ironizuje, że wydanie książki, której język podlega stylizacji wymagającej używania form wulgarnych, niepoprawnych, a nawet nieporadnych (język dziecka), jest na Łużycach aktem odwagi, ale może być też odbierany jako akt wandalizmu językowego. Rzeczywiście, formy językowe, które w dużych językach są traktowane jako zabieg literacki, w przypadku świata łużyckojęzycznego stają się problematyczne, a odbierane są jako „zabójcze” dla samego języka.

Dlaczego więc tłumacze pozwolili sobie na używanie germanizmów i stosowanie niepoprawnych form oraz pisanie w języku potocznym? Czy była to przyjęta strategia translatorska, czy działanie przypadkowe, wynikające z nieświadomości bądź nieznajomości języka? Oboje tłumacze mają ogromną wrażliwość językową, znają wiele języków słowiańskich, a także odznaczają się dużą świadomością sytuacji języków łużyckich. Zadana im do tłumaczenia książka jest natomiast napisana oryginalnie językiem, którym mogliby się porozumiewać uczniowie pierwszych klas szkoły podstawowej - to język dziecinny, czasem nieporadny, często nasycony błędami. Jak w języku górnołużyckim oddać taki sposób mówienia? Przysłuchując się językowi, którym posługuje się najmłodsze pokolenie Łużyczan², nie sposób nie zauważyć, że ich język jest inny niż ten używany przez górnołużycką inteligencję, daleko mu też do łużyckiego języka literackiego. Ciągły kontakt językowy, a przede wszystkim zanurzenie dzieci, nawet tych z górnołużyckojęzycznych rodzin, w środowisku i otoczeniu niemieckojęzycznym, powoduje, że zapożyczenia z języka niemieckiego są u nich na porządku dziennym. Tak dzieje się też w języku osób z innych pokoleń, jednak u dzieci jest to szczególnie widoczne, także ze względu na brak świadomości potrzeby rozłączania

2 W latach 2012-2014 i od początku 2017 roku miałam dużo kontaktów z młodymi Górnołużyczanami, z którymi w ramach dwóch kolejnych projektów badawczych prowadziłam pogłębione wywiady, a także obserwacje praktyk językowych w Łużyckim Gimnazjum w Budziszynie. 
tych języków w celu ochrony łużyckiego. Nie sposób więc oddać oryginału, nie sięgając po zapożyczenia z niemieckiego.

W wątkach i argumentach padających $\mathrm{w}$ dyskusji słychać echa panujących na Łużycach - i funkcjonujących również w innych wspólnotach mniejszości językowych ideologii językowych (Schieffelin, Woolard, Kroskrity 1998; Chromik 2016). Pierwszą z nich można określić jako ideologię autentyczności języka (Bucholtz 2003; Bucholtz, Hall 2004), z którą bezpośrednio związana jest druga ideologia - ideologia języka literackiego (Lippi-Green 2012). Ideologie te odnoszą się do pytania, jaki język jest „prawdziwy”: czy ten używany przez osoby żyjące we wspólnocie i posługujące się nim na co dzień, choćby stosowały code-switching (Eastman 1992), a ich język byłby pełen zapożyczeń, których zawsze w sytuacji kontaktów językowych, zwłaszcza związanych z nierównością dwóch języków (mniejszościowego i dominującego), pojawia się wiele? Czy raczej jest to język literacki, który stanowi wzór form językowych i który powinien być propagowany przez instytucje lub inteligencję danej grupy?

W przypadku dyskusji wokół górnołużyckiego przekładu książki Kratochvíla język „autentyczny”, a więc taki, jakim posługują się dzieci w codziennym życiu i kontaktach z najbliższymi, jest wyraźnie dewaloryzowany. Jedna z recenzentek (Šołćic 2016) pisze nawet, że obecnie język górnołużycki, którym posługują się przedstawiciele tej wspólnoty, jest tak „zniszczony” i „zanieczyszczony”, że staje w obliczu zagłady. Językiem literatury, a także językiem, który mają przyswoić młodzi - którego zatem używanie może uratować przyszłość łużyckiego - jest jego wersja literacka. Na język potoczny w publikacjach nie może być miejsca. Odwołując się do Lippi-Green (2012), taki wybór można by nazwać „ideologią języka standardowego", opartą na przekonaniu, że język w odmianie lokalnej, potocznej ma niższą wartość niż ten standardowy. Konsekwencją takiego spojrzenia może być odrzucenie innych form języka niż literacka. Język standardowy jest narzucany grupie jako „poprawny”, „właściwy” czy „obowiązujący”, co może prowadzić do konfliktów wewnątrz grupy (odmiany dialektalne), ale też spowodować, że język, którego używają starsze pokolenia - lub w tym przypadku pokolenia młodsze - traci wartość (zob. Bourdieu 1991). To z kolei może powodować opór wszystkich tych, którzy języka literackiego nie znają, a nawet - prowadzić do zaniechania przez nich mówienia w języku mniejszościowym.

Tymczasem dla trwania języka - zarówno jako narzędzia komunikacji codziennej, jak i materii literatury - potrzebne są jego różne formy. Zdaniem Joshui A. Fishmana (1991) standardowy, pisany język mniejszościowy powinien być nie tylko nauczany, ale też przez wspólnotę propagowany. Jest to zgodne z misją wydawniczą Domowiny. Jednocześnie jednak mniejszość za język „naturalny” uważa często ten, który wyniosła z domu, albo ten, który zna z najbliższej okolicy. Jest to język potoczny, pełen zapożyczeń z języka dominującego. Ten język traktują jako „swój”. Wywiady, jakie prowadziłam z młodymi Górnołużyczanami (Dołowy-Rybińska 2017), dowodzą, że wielu z nich nie sięga nigdy po literaturę w języku mniejszościowym, bo uważa ją za nudną, a język literacki za „sztuczny”. Książeczka Šwintuchaj może być dla nich zaskoczeniem. Konfrontacja języka literackiego, w którym „książka powinna być napisana”, z tym potocznym, którym napisana została, może nieść też istotne przesłanie i uzmysłowić czytelnikom, że obie formy są ważne i mają swoje role do odegrania we wspólnocie. 


\section{Mikroliteratura (dziecięca): edukować czy bawić?}

Publikowanie literatury w języku mniejszościowym, zwłaszcza tak małym jak język górnołużycki, nie jest działaniem komercyjnym. Wydawnictwo dotowane z pieniędzy państwowych za pośrednictwem specjalnego funduszu przeznaczonego na zachowanie i rozwój kultury i języków łużyckich wydaje stosunkowo niewiele pozycji ${ }^{3}$, w związku z czym każda decyzja wydawnicza musi być dobrze przemyślana. Dotyczy to także - a może przede wszystkim - książek dla dzieci. Z pewnością mają one służyć szeroko pojętej edukacji dzieci, a zwłaszcza uwrażliwianiu ich na język łużycki, którego jest przecież bardzo mało w audiosferze poza zwartym terenem zamieszkanym przez katolickich Górnołużyczan, a jeszcze mniej w logosferze regionu. Poprzez literaturę dzieci z łużyckojęzycznych domów mają oswoić się z pisaną formą języka, którą jedynie niektórzy mają szansę poznać w szkole (zob. Hornberger 2008). Literatura ma też duże znaczenie dla dzieci z niemieckojęzycznych rodzin, które uczą się od przedszkola w immersyjnym systemie kształcenia, gdzie spotykają się na co dzień z językiem łużyckim, są w nim „zanurzane” (Hinton 2001), przygotowywane do przejścia do dwujęzycznej szkoły podstawowej. Jednocześnie jednak dzieci te nie mają szansy na kontakt z językiem łużyckim poza placówkami edukacyjnymi. Łużyczanie tworzą bowiem dość zamknięte wspólnoty, zaś wydarzeń kulturalnych w języku górnołużyckim, zwłaszcza tych przeznaczonych dla małoletnich, jest niewiele. Nie ma telewizyjnych ani radiowych programów przeznaczonych dla najmłodszych odbiorców. Dlatego literatura, także w formie audiobooków, ma nie tylko edukować, ale również być łącznikiem niemieckojęzycznego dziecka z językiem górnołużyckim używanym poza szkołą.

Niektórzy recenzenci, w tym Hańža Winarjec-Orsesowa (2014), uważają, że książka wydawana na Łużycach przez wydawnictwo mniejszości powinna mieć przede wszystkim misję edukacyjną: dziecko powinno, czytając ją, przyswajać i utrwalać poprawny język łużycki, w jego odmianie literackiej, z którą rzadko ma szansę zetknąć się poza szkołą. Odnosi się to zwłaszcza do dzieci uczących się dopiero języka łużyckiego, które mogłyby utrwalić sobie potoczne formy wypowiedzi w miejsce tych uznawanych społecznie za poprawne. Krytycy zakładają wręcz, że (górnołużycką) książkę można czytać wyłącznie po to, by się uczyć. Uczenie się przyniosłoby zaś odwrotne do zamierzonych efekty, jeśli język książki przekazywałby formy niepoprawne, potoczne lub pełne zapożyczeń.

By lektura książki była istotna, ta musi być napisana językiem literackim. Recenzentka (ibid.) pisze wprost, że, jej zdaniem, jakakolwiek stylizacja językowa może przeszkodzić dziecku w lekturze - a tym samym w przyswajaniu poprawnych form językowych. Otóż, według niej, dzieci czeskojęzyczne, dla których książka była pisana, są swoim językiem macierzystym otoczone, potrafią więc radzić sobie z satyrą czy stylizacją. Tymczasem takie zabiegi językowe mogą dla dziecka łużyckojęzycznego, a zwłaszcza uczącego się tego języka, być mylące, a nawet prowadzić do utrwalania błędów i używania niepoprawnych form ję-

3 Choć porównując z innymi tego typu wydawnictwami, np. funkcjonującymi na Kaszubach, Ludowe Nakładnistwo Domowina wydaje się mieć bardzo dużą i zróżnicowaną ofertę; por. on-line na stronie: http://www. domowina-verlag.de [12.09.2017]. 
zykowych, przyswojonych podczas lektury. Autorka recenzji stawia tezę, że taka publikacja sama w sobie przyczynia się do zwiększenia stopnia zagrożenia łużycczyzny.

Jeśli pierwszą z misji mikroliteratury można określić jako edukacyjną, na co zwracają uwagę również przywoływani recenzenci, uważam, że drugą jej misją, wbrew pozorom niestojącą w sprzeczności z misją edukacyjną, jest zachęcanie - zwłaszcza młodych - odbiorców do kontaktów z językiem mniejszościowym. Jeśli będzie to język w formie pisanej, z którą mają znacznie mniejszy kontakt - tym lepiej. Żeby jednak (młodzi) ludzie chcieli z literaturą napisaną w języku mniejszościowym obcować, musi ona oferować im coś więcej niż tylko walory edukacyjne. Książka, choćby napisana najpoprawniejszym językiem literackim, która nie będzie dla czytelnika ciekawa, wciągająca, wzbudzająca emocji, nie spełni misji edukacyjnej, gdyż zostanie odrzucona lub zapomniana.

Badania dotyczące postaw ludzi wobec języków mniejszościowych dowodzą, jak ważna dla chęci zachowania języka jest jego atrakcyjność i wielość dostępnych form oraz miejsc jego używania (Baker 1992; Bradley 2002). Tymczasem na łużyckojęzycznym rynku wydawniczym Šwintuchaj jest książeczką wyjątkową, pisaną dla dzieci, stylizowaną na ich język, przedstawiającą przygody niekoniecznie grzecznych, ale jednak dających się lubić bohaterów, które z łatwością mogą rozśmieszyć czytelników, wciągnąć ich i zachęcić do dalszej lektury. Nawet jeśli samemu językowi przekładu, poza kwestiami ideologicznymi, można sporo zarzucić, wskazać na niekonsekwencje lub używanie błędnych językowo form, charakterystycznych dla języka dziecięcego, książeczka ta może mieć dla dzieci łużyckojęzycznych i dla uczących się większe znaczenie niż niejedna książka napisana poprawną łużycczyzną, do której żadne z nich nie będzie chciało zajrzeć.

\section{Dyskusja wokół przekładu: żywotność wspólnoty językowej czy jej kres?}

Na zakończenie warto zadać sobie pytanie, czy literatura mniejszościowa ma te same możliwości wyrazu co literatura pisana w dużych językach, a jeśli nie - gdzie leżą jej ograniczenia.

Pierwszy powód odpowiedzi negatywnej wydaje się oczywisty: w małej grupie użytkowników danego języka - jak w przypadku języków łużyckich - jest proporcjonalnie mniej twórców niż w społeczności o znacznych rozmiarach. Nie bez znaczenia pozostaje również to, że odbiorców literatury jest niewielu. Spośród całej społeczności, która danym językiem się porozumiewa, czytelników dzieł literackich trafia się zaledwie garstka. Oczywiście, stwierdzenie to w pewnym stopniu odnosi się do każdej społeczności językowej. Jednak gdy jest ona niewielka, liczby stają się naprawdę znaczące. To z kolei pociąga za sobą kolejny problem: na twórczości literackiej w języku mniejszościowym trudno zarobić.

Konsekwencje tego są dwojakie. Po pierwsze, z obawy o niemożność prowadzenia godnego życia wielu potencjalnych pisarzy nie zdecyduje się na poświęcenie się swojej pasji. Inni z kolei postanowią wydawać swoje utwory nie w języku mniejszościowym, ale dominującym, wchodząc tym samym do grona twórców państwowych. Po drugie, mniejszości mają ograniczoną liczbę wydawnictw, te z kolei budżet pozwalający im na wydawanie niewielu pozycji. A to w zasadzie uniemożliwia publikowanie wszechstronnej i różnorodnej 
literatury w języku mniejszościowym. Wydawnictwa mniejszości w Europie w dużej mierze są bowiem dotowane $\mathrm{z}$ pieniędzy przeznaczonych przez państwo/region/administrację terytorialną na ochronę i zachowanie języka oraz kultury mniejszościowej. Na Łużycach, jak pisałam w sekcji 1, działalność wydawnicza realizowana przez Ludowe Nakładnistwo Domowina jest dotowana ze statutowych funduszy Fundacji na rzecz Narodu Łużyckiego. Nie ma możliwości, żeby w tak małej grupie utrzymało się wydawnictwo komercyjne $e^{4}$. Oznacza to, że pieczę nad doborem literatury, którą warto/należy wydać, mają instytucje rozdające środki finansowe, a więc konkretna grupa liderów etnicznych. Ich wybory są podporządkowane prowadzonej polityce językowej, a często też odzwierciedlają wizję pewnej grupy decydentów samej mniejszości i jej literatury. Co oznacza to w praktyce? Nierzadko wolność artystyczna twórców mniejszościowych musi zostać podporządkowana misji wydawniczej i dopasować się do propagowanego wizerunku kultury mniejszościowej. Przez mniejszościowe wydawnictwo, zwłaszcza takie, które - jak na Łużycach - jest monopolistą, promowane są konkretne tematy, formy językowe, a nawet opinie. Nie ma miejsca na „język giętki” i nieskrępowaną twórczość artystyczną.

Żeby pokazać, z jakimi problemami musi mierzyć się literatura pisana w bardzo małym języku, celowo nie wybrałam utworu, który miałby dla tej grupy duże znaczenie. Opisana przeze mnie dyskusja toczyła się wokół przekładu czeskiej książeczki dla dzieci, zwykłej „poczytajki”, która w normalnych warunkach zostaje przez dzieci i czytających im rodziców szybko zapomniana, choć jej lektura sprawia przyjemność. Jednocześnie jednak spory wokół książki trwały kilka lat i nie zakończyły się definitywnie. Sami przedstawiciele łużyckiej elity zaczęli szybko dostrzegać ten paradoks i zwracać nań uwagę. Měrćin Wjenk (2014) w felietonie „Rozhladu” zastanawia się, o czym dyskusja wokół książki świadczy, i dochodzi do wniosku, że Łużyczanie starając się ograniczać wolność twórczą i wskazywać, jakie formy językowe mogą być dopuszczane do użycia w literaturze, a jakie powinny być zakazane, sami siebie zamykają w skansenie. Stwierdza, że ograniczanie twórczości do realizowania misji, którą jest zachowanie języka mniejszościowego, świadczyłoby o tym, że kultura przestała już być żywa.

Tymczasem kultura łużycka jak najbardziej jest wciąż żywa: jej przedstawiciele realizują swoje pomysły, tworzą, poszukują różnych dróg własnego rozwoju, jak i możliwości ochrony swoich języków. Niektórzy twórcy ograniczenia związane z monopolizacją wydawnictwa i środków skierowanych na twórczość, również pisarską, obchodzą dzięki internetowi i dawanym przezeń możliwościom. Inni starają się przekonywać decydentów i twórców polityki językowej, że różnorodność, nawet wewnątrz tak małej grupy, jest ważna i potrzebna.

Książka Šwintuchaj nie przetrwa zapewne próby czasu, nie stanie się ważną pozycją łużyckiego rynku wydawniczego. Niezamierzenie stała się jednak motorem istotnej dyskusji wewnątrzśrodowiskowej. Udało się jej na dodatek spełnić zarówno misję rozrywkową, jak i edukacyjną. Cała opowieść, niezależnie od tego, jak istotne można mieć zarzuty do wyborów językowych tłumaczy, dotyczy losów dwóch chłopców. Stale używana jest w niej więc forma liczby podwójnej, tzw. dualu, która w większości języków słowiańskich zanikła, a i na

\footnotetext{
${ }^{4}$ Nie wszystkie mniejszości językowe Europy mają taki problem. Niektóre grupy, o znacznie większej liczbie użytkowników języka mniejszościowego i osób z daną zbiorowością się identyfikujących, dysponują wieloma wydawnictwami publikującymi literaturę w języku mniejszościowym i/lub dla mniejszości. Do takich mniejszości można zaliczyć Katalończyków czy Walijczyków.
} 
Łużycach jest coraz silniej - zwłaszcza przez młode pokolenie - ignorowana. Po przeczytaniu Šwintuchaj chciałoby się dualu używać ciągle. I może właśnie ta forma gramatyczna zostanie przez młodych czytelników zinternalizowana dzięki lekturze, nie zaś germanizmy czy pojawiające się w książce błędy językowe.

\section{Bibliografia}

\section{Literatura podmiotu}

Diskusija 2014. „Serbske Nowiny” 1.08.2014.

Kratochvíl, Miloš 2009. Puntíkáři. Praha: Mladá fronta.

— 2013. Šwintuchaj. Przełożyli Jadwiga i Fabian Kaulfürst. Budyšin: Ludowe nakładnistwo Domowina.

Nuk, Michał 2014. Recenzja przekładu książki Šwintuchaj. „Serbske Nowiny” 24.01.2014.

Šołćic, Wórša 2014. „Maćernu rěč lubuju [Kocham język ojczysty]”. Rozhlad 7-8: 25.

—2016. „Jurij Brězan ma jasnu wotmołwu [Jurij Brězan ma jasną odpowiedź]”. Rozhlad 9: 36.

Winarjec-Orsesowa, Hańža 2014. „Wažmy sej dźědźinstwo serbskeje rěče [Szanujmy dziedzictwo języka łużyckiego]!”. Rozhlad 10: 22-25.

Wjenk, Měrćin 2014. „Zabyli smy zabyć [Zapomnieliśmy zapomnieć]”. Rozhlad 10:2.

Žurowa, Weronika 2016. Recenzja przekładu książki Šwintuchaj. „Serbske Nowiny” 10.06.2016.

\section{Literatura przedmiotu}

Baker, Colin 1992. Attitudes and languages. Clevedon: Multilingual Matters.

Bourdieu, Pierre 1991. Language and symbolic power. Cambridge: Polity Press.

Bradley, David 2002. „Language attitudes: the key factor in language maintenance”. W: David Bradley, Maya Bradley (red.). Language endangerment and language maintenance. LondonNew York: Routledge. 1-10.

Bucholtz, Mary 2003. „Sociolinguistic nostalgia and the authentication of identity”. Journal of Sociolinguistics 7 (3): 389-416.

Bucholtz, Mary, Kira Hall 2004. „Language and identity”. W: Alessandro Duranti (red.). A companion to linguistic anthropology. Oxford: Basil Blackwell. 369-394.

Budarjowa, Ludmila 2009. Witaj und 2plus - eine Herausforderung für die Zukunft. Bautzen: Sorbischer Schulverein e.V.

Chromik, Bartłomiej 2016. „From Wilamowice to the philosophy of science and back again. Three levels of linguistic ideologies". W: Justyna Olko, Tomasz Wicherkiewicz, Robert Borges (red.). Integral strategies for language revitalization. Warszawa: Wydział Artes Liberales. 91-109.

Dołowy-Rybińska, Nicole 2011. Języki i kultury mniejszościowe w Europie: Bretończycy, Łużyczanie, Kaszubi. Warszawa: Wydawnictwa Uniwersytetu Warszawskiego.

— 2012. „Witalizacja i rewitalizacja - strategie zachowania języków mniejszościowych na Górnych i Dolnych Łużycach”. W: Grażyna Barbara Szewczyk (red.). Serbołużyczanie wobec tradycji i wyzwań teraźniejszości. Język - literatura - kultura. Katowice: Wydawnictwo Naukowe Śląsk. 39-57. 
2017. „Nikt za nas tego nie zrobi”. Praktyki językowe i kulturowe młodych aktywistów mniejszości językowych Europy. Toruń: Wydawnictwo Naukowe UMK.

Eastman, Carol M. 1992. Codeswitching. Clevedon: Multilingual Matters.

Elle, Ludwig 2010. „Sorben - demographische und statistische Aspekte”. W: Matthias Theodor Vogt, Jürgen Neyer, Dieter Bingen, Jan Sokol, Albert Löhr (red.). Minderheiten als Mehrwert. Frankfurt am Main: Peter Lang. 309-318.

Fishman, Joshua A. 1991. Reversing language shift. Theoretical and empirical foundations of assistance to threatened languages. Clevedon: Multilingual Matters.

Gantefort, Christoph, Hans-Joachim Roth, Natalia Migai, Ingrid Gogolin 2010. Sorbisch-deutsche Schulen in Sachsen: Ergebnisse zur Sprachentwicklung in der Sekundarstufe. Hamburg-Köln: Universität Hamburg, Universität zu Köln.

Hinton, Leanne 2001. „New Writing Systems”. W: Leanne Hinton, Kenneth L. Hale (red.). The green book of language revitalization in practice. San Diego: Academic Press. 239-250.

Hornberger, Nancy H. (red.) 2008. Can schools save indigenous languages? Policy and practice on four continents. Hampshire: Palgrave Macmillan.

Jodlbauer, Ralph, Gunter Spiess, Han Steenwijk 2001. Die aktuelle Situation der niedersorbischen Sprache. Ergebnisse einer soziolinguistischen Untersuchung der Jahre 1993-1995. Bautzen: Domowina-Verlag.

Lippi-Green, Rosanna 2012. English with an accent. Language, ideology, and discrimination in the United States. London-New York: Routledge.

Norberg, Madlena 1996. Sprachwechselprozeß in der Niederlausitz: Soziolinguistische Fallstudie der Deutsch-Sorbischen Gemeinde Drachhausen/Hochoza. Uppsala: Studia Slavica Uppsalensia.

Sankoff, Gillian 2001. „Linguistic Outcomes of Language Contact”. W: Peter Trudgill, J. K. Chambers, Natalie Schilling-Estes (red.). Handbook of language variation and change. Oxford: Basil Blackwell. 638-668.

Schieffelin, Bambi B., Kathryn A. Woolard., Paul V. Kroskrity (red.) 1998. Language ideologies: practice and theory. New York: Oxford University Press.

Walde, Martin 2004. „Demographisch-statistische Betrachtungen im Oberlausitzer Gemeindeverband Am Klosterwasser". Lètopis 51 (1): 3-27. 